\title{
Optimalisasi Peran Guru dan Orang Tua dalam Pembelajaran Online pada Masa Pandemi Covid-19
}

\author{
Hajeni $^{1 凶}{ }^{\bowtie}$ Rahmatia $^{1}$, Marhani ${ }^{2}$, Lulu Febrianti ${ }^{1}$ \\ Pendidikan Guru Pendidikan Anak Usia Dini, Universitas Muhammadiyah Palopo, \\ Indonesia(1); Bimbingan dan Konseling, Universitas Muhammadiyah Palopo, Indonesia(2) \\ DOI: $10.31004 /$ obsesi.v6i4.2327
}

\begin{abstract}
Abstrak
Optimalisasi peran guru dan orang tua berpengaruh terhadap capaian proses pembelajaran AUD. Penelitian ini bertujuan menggambarkan optimalisasi peran guru dan orang tua dalam pembelajaran sistem online AUD pada masa pandemic covid-19 di Kota Palopo. Jenis penelitian deskriptif kualitatif dengan subjek 70 orang guru, orang tua, dan kepala sekolah. Teknik pengumpulan data menggunakan wawancara dan kuesionar dalam bentuk google form yang dianalisis dengan Teknik analysis interacative Model, uji keabsahan data menggunakan Teknik triangulasi. Hasil penelitian menggambarkan bahwa optimalisasi peran guru dan orang tua yaitu: 1) membuat video tutorial; 2) melakukan video call; 3) melaksanakan pembelajaran melalui zoom, WhatsApp; 4) membuat alat peraga yang menarik; 5) melakukan Visit Home; 6) mengumpulkan video pembelajaran, foto, LKA dan hasil karya anak,7) mendampingi anak saat pembelajaran berlangsung; 8) mengawasi dan membimbing anak mengerjakan LKA dan membuat video; 9) membuat laporan kepada guru. Adapun implikasi dari penelitian ini yaitu, penelitian ini dapat menggambarkan bagaimana mengoptimalkan peran guru dan orang tua dalam pembelajaran sistem online anak usia dini pada masa pandemi covid-19.
\end{abstract}

Kata Kunci: optimalisasi; peran guru; orang tua

\begin{abstract}
Optimizing the role of teachers and parents affects the achievement of the AUD learning process. This study aims to describe the optimization of teachers' and parents' role in learning the AUD online system during the COVID-19 pandemic in Palopo. This is a qualitative descriptive research with the subject of 70 teachers, parents, and principals. The data collection technique used interviews and questionnaires in the form of google form which was analyzed by using interactive model analysis technique, the validity of the data was tested using triangulation techniques. The results of the study illustrate that the optimization of the teachers' and parents' role are: 1) making tutorials video; 2) doing video calls; 3) Conducting learning via zoom, WhatsApp; 4) make interesting props; 5) do a Home visit; 6) collect learning videos, photos, worksheets and children's work, 7) accompanying children during learning; 8) supervising and guiding children in doing the LKA and making videos; 9) make a report to the teacher. The implications of this research are that this research can describe how to optimize the role of teachers and parents in online learning for early childhood during the COVID-19 pandemic.
\end{abstract}

Keywords: optimization; teachers' role; parents' role

Copyright (c) 2022 Hajeni, et al.

$\triangle$ Corresponding author :

Email Address : hajeni@umpalopo.ac.id (Palopo, Sulawesi Selatan, Indonesia)

Received 24 October 2021, Accepted 23 February 2022, Published 23 February 2022 


\section{PENDAHULUAN}

Awal tahun 2020 merupakan masa duka bagi Indonesia setelah diumumkannya 2 kasus warga negara Indonesia positif Corona Virus desease 2019 (Covid-19). Dengan semakin meningkatnya kasus positif Covid-19 di Indonesia, berdampak pada berlakunya kebijakan Belajar Dalam Jaringan (Daring) yang diumumkan oleh pemerintah. Belajar yang semula dilaksanakan dengan tatap muka, harus dilaksanakan dari rumah dengan sistem daring/ online untuk mencegah dan menanggulangi penyebaran virus Covid-19. Hal ini tidak hanya berlaku bagi perguruan tinggi namun ini berlaku pada semua Lembaga Pendidikan termasuk di dalamnya lembaga Pendidikan Anak Usia Dini (PAUD) (Arifa, 2020).

Anak usia dini (AUD) dapat didefinisikan sebagai anak yang berusia 0-8 tahun yang merupakan masa pertumbuhan dan perkembangan yang sangat penting dalam kehidupan anak. Usia ini merupakan usia emas bagi anak untuk berkembangnya 6 aspek AUD yakni kognitif, bahasa, nilai agama moral, seni, psikomotrik halus dan kasar serta sosial emosional (Hasanah, 2018), dalam lingkungan Pendidikan yaitu Lembaga PAUD. Munculnya virus Covid-19 sebagaimana dijelaskan sebelumnya, berdampak pada pembelajaran AUD yakni diterapkannnya sistem pembelajaran online. Pembelajaran sistem online pada Lembaga PAUD ternyata memunculkan berbagai macam masalah yakni AUD tidak dapat belajar sendiri tanpa bantuan guru dan orang tua. Dengan demikian keterlibatan antar keduanya sangat penting dalam mendampingi anak belajar (Iftitah \& Anawaty, 2020).

Peran guru dan orang tua sangat berpengaruh terhadap capaian proses pembelajaran selama di rumah oleh karena itu kerja sama antar keduanya sangat diperlukan dalam pendampingan anak (Pertiwi et al., 2021). Orang tua merupakan tempat terjadinya interaksi Pendidikan yang pertama. Orang tua merupakan guru bagi anak sebelum memasuki usia sekolah (Rahmatullah et al., 2021), selain itu sebelum diberlakukannya pembelajaran daring orang tua berperan dalam membentuk karakter anak. Jika kondisi sebelum adanya pandemi dengan alasan berbagai macam kesibukan, orang tua menyerahkan sepenuhnya pembelajaran anak kepada guru di sekolah. Namun dengan adanya pandemi ini orang tua harus lebih mengoptimalkan peran dalam mendampingi anak belajar secara online. Menurut hasil penelitian Alfiah bahwa Pendidikan mengharuskan peran orang tua lebih besar dalam pengawasan dan pembelajaran di rumah (Alfiah et al., 2020).

Peran orang tua dalam mendampingi anak belajar online bukanlah hal yang mudah. Orang tua harus dapat membagi waktu mengurus keluarga, menyelesaikan pekerjaan kantor bagi yang bekerja dan meluangkan waktu mendampingi anak saat belajar. Peran orang tua yang sebelumnya lebih fokus pada penanaman sikap yang baik, menanamkan nilai agama pada anak, namun perannya makin meluas yakni sebagai pendamping akademik (Kurniati et al., 2020). Orang tua sebagai pendamping akademik memerlukan pemahaman terkait materi-materi pembelajaran anak usia dini sehingga komunikasi orang tua dan guru harus lebih intensif. Selain komunikasi dengan guru yang tak kalah pentingnya juga yakni penguasaan orang tua terhadap media pembelajaran daring seperti whatsApp, zoom, google classroom, google meet dan beberapa media pembelajaran lainnya.

Sementara itu dengan pemberlakuan sistem belajar online pada anak usia dini, bukan berarti bahwa peran guru dialihkan sepenuhnya menjadi tanggung jawab orang tua sebagai pendamping akademik di rumah. Peran guru tidak akan pernah tergantikan dengan apapun dan siapapun. Peran guru sebagai pembimbing untuk menumbuhkan minat dan bakat anak didik yang merupakan individu yang memiliki keunikan masing-masing. Di samping itu guru sebagai pelatih, proses pembelajaran yang dilakukan guru diharapkan mampu untuk meningkatkan keterampilan motorik anak didik. Selanjutnya guru sebagai penasehat, dalam hal membantu anak didik yang mengalami kesulitan dalam proses pembelajaran. Sementara itu guru sebagai pendorong kreativitas dituntut untuk memberikan stimulus pada anak didik untuk menciptakan sesuatu yang baru. (Indah et al., 2020)

Peran guru tidak hanya sebagai pembimbing, pelatih dan penasehat sebagaimana yang dijelaskan di atas namun guru juga berperan sebagai komunikator dalam hal ini 
melakukan komunikasi dengan anak didik dan masyarakat. Guru juga berperan sebagai model, dengan memberikan contoh prilaku yang baik bagi anak didik. Sebagai motivator, guru harus dapat meningkatkan gairah atau minat belajar anak didik dalam kegiatan pembelajaran. Sedangkan guru sebagai evaluator dalam melakukan evaluasi capaian pembelajaran.(Affifah, 2021) meskipun pembelajaran dilaksanakan dengan sistem online, guru tetap harus tetap melaksanakan penilaian pembelajaran berdasarkan laporan orang tua.

Berdasarkan penjelasan di atas maka disimpulkan bahwa peran guru dan orang tua sangat penting dalam pembelajaran sistem online oleh karena itu perlu adanya optimalisasi peran orang tua dan guru dalam mendampingi anak belajar di rumah pada masa Pandemi Covid-19. Inilah yang menjadi dasar pemikiran pelaksanaan penelitian dengan judul "optimalisasi peran guru dan orang tua dalam pembelajaran sistem online anak usia dini pada masa pandemi covid-19 di Kota Palopo" beberapa peneliti sebelumnya telah melakukan penelitian tentang peran guru atau peran orang tua, seperti penelitian yang dilaksanakan oleh kurniati dengan judul "analisis Peran Orang Tua dalam Mendampingi Anak di Masa Pandemi Covid-19". Selain itu penelitian yang dilakukan Rahmatullah dengan judul "Efektifitas Peran Guru dan Orang Tua dalam Pembelajaran Daring Selama pandemic Covid19". Penelitian yang juga dilaksanakan oleh Kristiana Mariyani dengan judul "Peran Guru dalam Pelaksanaan Pembelajaran di Rumah pada Anak Usia Dini". Penelitian tersebut merupakan beberapa penelitian awal yang berkaitan erat dengan penelitian ini, namun penelitian ini memiliki keterbaharuan yang berbeda dengan penelitian sebelumnya dengan dasar bahwa penelitian ini akan mengkaji optimalisasi peran guru dan orang tua dalam sistem pembelajaran online anak usia dini pada masa Covid-19 dengan menggunakan fungsi manajemen yakni perencanaan, pelaksanaan, dan evaluasi.

Penelitian ini bertujuan untuk mengkaji tentang optimalisasi peran guru dan orang tua dalam sistem pembelajaran online anak usia dini pada masa Covid-19 dengan harapan bahwa penelitian ini dapat menambah khasanah keilmuan yang berkaitan dengan judul penelitian serta untuk guru dan orang tua dapat menjadi bahan renungan untuk menjalankan peran masing-masing selama pembelajaran masa pandemi Covid-19.

\section{METODOLOGI}

Jenis penelitian adalah deskriptif kualitatif dengan menggunakan pendekatan fungsi manajemen untuk mengkaji secara mendalam tentang optimalisasi peran guru dan orang tua dalam sistem pembelajaran online anak usia dini pada masa covid-19. Penelitian ini dilaksanakan selama 3 bulan yaitu bulan Juli-September 2021 di Kota Palopo. Adapun yang menjadi subjek penelitian yakni Guru PAUD sebanyak 29 orang dan orang tua anak usia dini 20 orang sebagai informan utama, sedangkan serta kepala sekolah sebanyak 20 orang sebagai informan pendukung. Alasan pemilihan responden ini berdasarkan masalah yang akan diteliti dan kebutuhan responden di lapangan. Adapun teknik pengumpulan data yang digunakan yakni wawancara dan menggunakan kuesionar melalui platform google form. Data penelitian dianalisis dengan 3 tahapan yakni reduksi data, display data dan penyajian data dengan mengacu pada teori analisis data model Miles dan Huberman (Iftitah \& Anawaty, 2020). Untuk mengecek keabsahan data maka dilakukan triangulasi sumber yakni membandingkan data yang diperoleh dari semua informan. Adapun teknis analisis data dalam penelitian ini dapat dilihat pada bagan gambar 1 . 


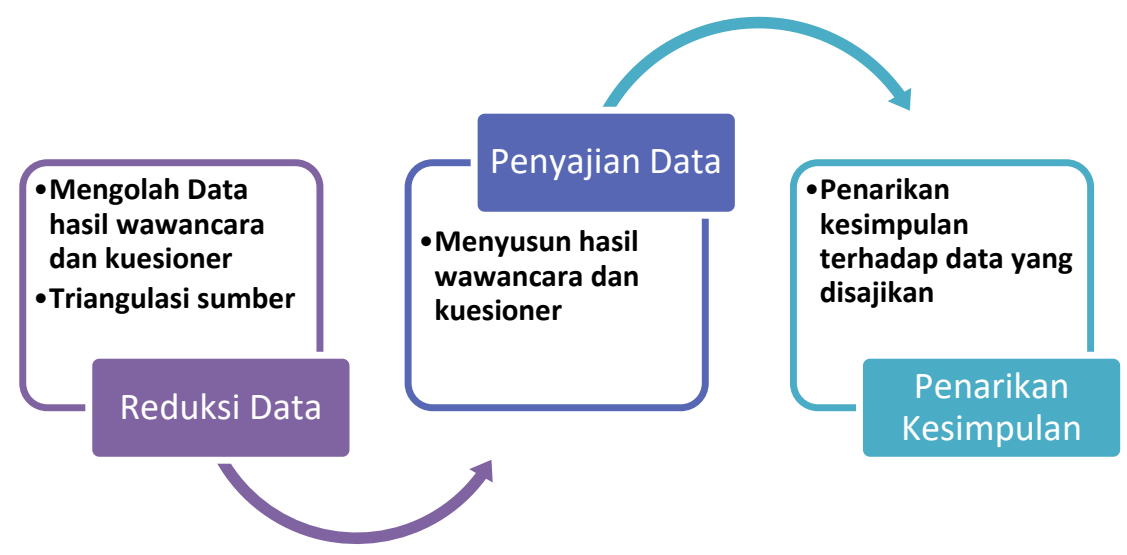

Gambar 1. Teknik Analisis Data Model Miles dan Huberman

\section{HASIL DAN PEMBAHASAN}

Pandemi Covid-19 mengubah sistem pendidikan yang berfokus di sekolah kini berpindah ke rumah dengan pembelajaran sistem online, hal ini tentu berpengaruh pada peran guru dan orang tua dalam proses pembelajaran. Sebelum adanya wabah ini, guru bertanggung jawab penuh terhadap pendidikan anak di sekolah namun karena kondisi ini maka orang tua beralih peran mendampingi proses pembelajaran dengan sistem online yang dilaksanakan di rumah. Dengan pemberlakuan pembelajaran sistem online bukan berarti mengubah substansi capaian pembelajaran anak didik, oleh karena itu baik guru maupun orang tua harus membangun komunikasi dalam menjalankan peran masing-masing untuk terlaksanakanya pembelajaran yang efektif demi mencapai tujuan pembelajaran sebagaimana yang tercantum dalam kurikulum anak usia dini. Oleh karena itu optimalisasi peran guru dan orang tua menjadi satu hal yang penting saat ini sehingga menjadi focus penelitian ini. Adapun hasil penelitian yang didapatkan dengan menggunakan teknik wawancara dan menyebarkan kuesioner kepada guru, orang tua dan kepala sekolah PAUD di Kota Palopo tentang optimalisasi peran guru dan orang tua dalam pembelajaran sistem online anak usia dini pada masa pandemi Covid-19 dapat diuraikan pada pembahasan selanjutnya.

\section{Optimalisasi Peran Guru dalam Pembelajaran Sistem Online Anak Usia Dini pada Masa Pandemi Covid-19 di Kota Palopo}

Peran guru tidak akan tergantikan meskipun pembelajaran dilaksanakan dari rumah. Guru tetap melaksanakan tugas dalam menyusun perencanaan pembelajaran, melaksanakan pembelajaran dan melakukan evaluasi atau penilaian terhadap perkembangan anak usia dini. Optimalisasi peran guru dalam merencanakan, melaksanakan dan mengevaluasi pembelajaran sangat penting dalam sistem pembelajaran online. Oleh karena itu berdasarkan hasil penelitian yang dilakukan dengan Teknik wawancara dan menyebar kuesioner dalam bentuk google form kepada guru dan kepala sekolah diperoleh informasi terkait optimalisasi peran guru dalam pembelajaran online anak usia dini dapat dilihat pada gambar 2.

Berdasarkan gambar 2 dapat diuraikan bahwa untuk mengoptimalkan peran guru dalam sistem pembelajaran online anak usia dini, maka guru membuat beberapa perencanaan yakni membuat Rencana Pelaksanaan Pembelajaran Mingguan (RPPM). Pada gambar tersebut dapat dilihat bahwa 56 guru atau 80\% tetap membuat RPPM yang memuat tentang tema, sub tema, kompetensi dasar, muatan materi pembelajaran, dan rencana kegiatan, sebagai acuan orang tua dalam mendampingi anak belajar di rumah. Selanjutnya dari RPPM ini diturunkan menjadi Rencana Pelaksanaan pembelajaran Harian (RPPH) khusus untuk pembelajaran daring yang di susun oleh 38 guru atau 54,3\%. Selain itu 57 orang atau 81,4\% guru tetap membuat lembar kerja anak yang diberikan kepada orang tua setiap minggu. Selain 
lembar kerja, guru juga membuat video yang menarik dan menyenangkan berdasarkan tema pembelajaran untuk dipraktekkan anak dengan bantuan orang tua. Setiap minggu orang tua menyetor kembali lembar kerja anak dan mengirimkan video pembelajaran anak melalui media WhatsApp kepada orang tua. Berdasarkan lembar kerja, foto dan video yang dikirim oleh orang tua, guru melakukan penilaian terhadap capaian perkembangan anak berdasarkan kompetensi dasar yang termuat dalam RPPH belajar daring. Senada dengan pendapat Affifah (2021) bahwa Melaksanakan evaluasi atau penilaian ini berkaiatan dengan peran guru sebagai evaluator dalam kegiatan pembelajaran.

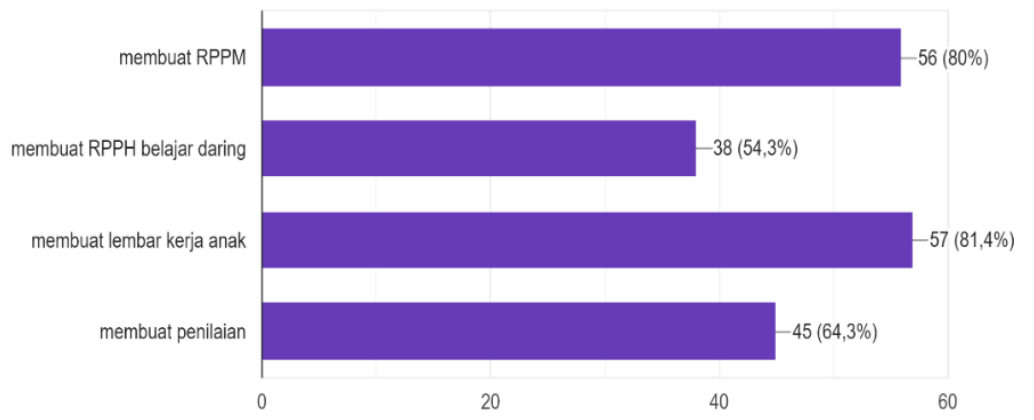

Gambar 2. Perencanaan Guru dalam Pembelajaran Sistem Online

Berdasarkan hasil kuesioner yang disebar kepada guru dan kepala sekolah pelaksanaan yang dilakukan untuk mengoptimalkan peran guru dapat dilihat pada gambar 3.

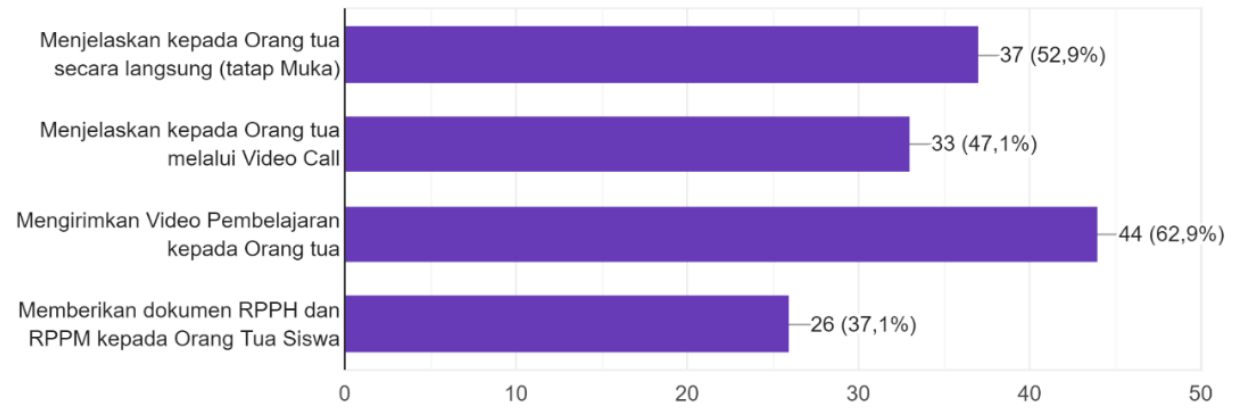

\section{Gambar 3. Pelaksanaan Guru dalam Pembelajaran Sistem Online}

Melalui gambar 3 terlihat bahwa untuk mengoptimalkan capaian pembelajaran 37 atau $52,9 \%$ guru menjelaskan kepada orang tua dengan tatap muka dan melalui video call sebanyak 33 orang atau $47,1 \%$. Selain itu guru juga mengirimkan video pembelajaran serta memberikan dokumen RPPH dan RPPM kepada orang tua. Ini dilakukan guru untuk membantu orang tua dalam memahami capaian pembelajaran agar orang tua tidak mengalami kesulitan dalam mendampingi anak belajar secara online baik melalui media WhatsApp atau media pembelajaran daring lainnya. Selain gambar 3 uraian pelaksanaan pembelajaran guru dapat dilihat pada tabel 1.

Tabel 1 memberikan gambaran peran guru sebagai pengajar dalam melaksanakan pembelajaran yang merupakan peran utama bagi guru (Darmadi, 2015). Pelaksanaan pembelajaran dilakukan menggunakan media zoom, dan WhatsApp. Hal ini senada dengan hasil penelitian Dewi (2020) bahwa pelaksanaan Pembelajaran Jarak Jauh menggunakan media zoom meeting dan WhatsApp. Selain itu guru membuat video tutorial materi pembelajaran yang menarik dan memperlihatkan guru yang sedang mengajar sehingga anak seolah-olah belajar seperti biasa di sekolah. Hal ini didukung oleh hasil penelitian (Syafi'i et al., 2020), bahwa video pembelajaran yang berisi video guru mengajar di kelas yang di share 
melalui grup menyebabkan anak percaya diri dan seolah-olah belajar di sekolah normal. Hasil penelitian yang sama juga dikemukakan oleh Wahyuni (2021) bahwa dengan menggunakan video pembelajaran sebagai media daring menyebabkan anak lebih mudah memahami pembelajaran, karena dalam penyampaian yang dikemas guru nampak hadir meskipun melalui video, sehingga anak-anak tertarik dengan adanya guru.

Tabel 1. Pelaksaan Pembelajaran Guru dalam Pembelajaran Sistem Online

\begin{tabular}{ll}
\hline No. & \multicolumn{1}{c}{ Uraian Kegiatan Pelaksanaan Pembelajaran } \\
\hline $\mathbf{1}$ & Guru memberikan dokumen RPPM dan RPPH kepada orang tua \\
2. & $\begin{array}{l}\text { Guru membuat video tutorial pembelajaran sehingga orang tua dengan mudah } \\
\text { menjelaskan dan membantu anak dalam mempraktekkannya }\end{array}$ \\
3. & $\begin{array}{l}\text { Guru menjelaskan secara langsung melalui tatap muka atau video call tentang } \\
\text { materi pembelajaran }\end{array}$ \\
4. & $\begin{array}{l}\text { Menjelaskan pembelajaran melalui zoom, WhatsApp kepada AUD dengan di } \\
\text { damping orang tua }\end{array}$ \\
5. & Membuat alat peraga yang menarik untuk AUD \\
6. & Melakukan evaluasi atau penilaian terhadap capaian perkembangan AUD \\
7. & Melakukan kunjungan rumah/ Visit Home maksimal 3 kali dalam sepekan \\
\hline
\end{tabular}

Selain video praktek mengajar, video pembelajaran yang diberikan sebagai unjuk kerja anak yang dipraktekkan oleh anak didik dengan bantuan orang tua bertujuan untuk meningkatkan dan melatih psikomotorik anak usia dini merupakan tanggung jawab guru sebagai pelatih. Ini sejalan dengan hasil penelitian Asmidarwati di mana dalam penelitian tersebut guru menggunakan video pembelajaran untuk meningkatkan kemampuan motorik kasar anak usia dini (Asmidarwati, Salmiati, 2020).

Hasil wawancara dengan guru juga menjelaskan bahwa guru juga berperan sebagai motivator dan penasehat. Hal ini sebagai penguatan yang diberikan kepada anak agar tidak merasa bosan. Guru memberikan motivasi berupa pujian kepada anak didik yang aktif mengirimkan hasil kerjanya. Hal ini sejalan dengan hasil penelitian Rendy Setyowahyudi bahwa guru memberikan penguatan verbal berupa pujian dan apresiasi kepada anak dalam penelitiannya yang berjudul "Keterampilan Guru PAUD Kabupaten Ponorogo Dalam Memberikan Penguatan Selama Pasa Pandemi Covid-19" (Rendy, 2020). Tak hanya itu guru juga memberikan semangat dan menanyakan kabar anak setiap hari sebagai bentuk motivasi guru kepada anak didiknya. Ini merupakan peran guru sebagai motivator (Sitti Maimunawati, 2020). Guru menasehati anak didik untuk mengikuti pembelajaran dan bahkan guru juga mendorong dan memberikan motivasi kepada orang tua untuk mendamping anak selama pembelajaran online berlangsung melalui video call dengan anak atau dengan menyapa melalui grup WhatsApp, ini bertujuan untuk membangkit semangat anak belajar di rumah di dampingi oleh orang tua, dan juga untuk menghilangkan rasa bosan pada anak usia dini. Pemberian motivasi ini merupakan salah satu peran guru yang sangat penting pada masa pandemi ini di mana anak usia dini memang memiliki karakteristik untuk cenderung bermain (Fadlillah, 2019). Melalui bermain dapat meningkatkan daya kreativitas anak, namun bermain seraya belajar sehingga guru harus dapat memberikan motivasi agar anak mau mengikuti pembelajaran secara online di rumah. hal ini sejalan dengan apa yang dikemukakan oleh Sundari faulina dalam penelitiannya yang berjudul "peran guru sebagai pembelajar dalam memotivasi peserta didik usia SD"(Sundari, 2017).

Kegiatan kunjungan rumah yang dilakukan maksimal 3 kali dalam seminggu bertujuan untuk melihat kegiatan belajar yang dilakukan anak di rumah. Berdasarkan data hasil wawancara dengan guru menjelaskan bahwa kunjungan rumah dilakukan karena beberapa keterbatasan yang dimiliki orang tua terutama orang tua yang memiliki keterbatasan ekonomi sehingga tidak mampu menyediakan fasilitas belajar online seperti gadget kepada anak di samping itu beberapa orang tua juga tidak mampu 
mengoperasikannya. Dengan dasar itu guru melakukan kunjungan rumah (visit home). Kegiatan ini juga dilakukan oleh guru yang berada di daerah 3T berdasarkan hasil penelitian Besse Nirmala dengan judul "Home Visit: Strategi PAUD dari Rumah Bagi Guru di Daerah 3T Pada Masa Pandemi Covid-19"(Nirmala \& Annuar, 2020). Adapun kegiatan evaluasi yang dilakukan oleh guru dapat dilihat pada tabel 2.

Tabel 2. Kegiatan Evaluasi/ Penilaian Guru dalam Pembelajaran Sistem Online

\begin{tabular}{ll}
\hline No. & \multicolumn{1}{c}{ Uraian Kegiatan Evaluasi/Penilaian Guru } \\
\hline 1. & Guru melakukan kunjungan maksimal 3 kali seminggu \\
\hline 2. & Guru melakukan Video Call dengan orang tua \\
\hline 3. & $\begin{array}{l}\text { Guru meminta kepada orang tua untuk mengirimkan video pembelajaran, } \\
\text { foto-foto saat kegiatan pembelajaran berlangsung melalui grup WhatsApp }\end{array}$ \\
\hline 4. & Mengumpulkan Lembar Kegiatan Anak (LKA) setiap minggu \\
\hline 5. & Mengumpulkan hasil karya anak \\
\hline
\end{tabular}

Pelaksanan evaluasi atau penilaian penting dilakukan guru untuk melihat capaian perkembangan anak meskipun pembelajaran dilaksanakan dengan sistem online. Salah satu bentuk penilaian yang dilakukan guru yaitu mengumpulkan hasil karya dan lembar kegiatan anak. Hal ini sejalan dengan hasil penelitian (Riski Maulinda Sari, Rodhatul Jennah, 2021) bahwa penilaian dilakukan dengan hasil karya. Selain itu hasil penelitian (Astuti \& Harun, 2020) mendukung penelitian ini dengan hasil penelitian bahwa penilaian dilakukan melalui video dan foto. Senada dengan Penelitian (Kemala \& Rohman, 2021) menjelaskan bahwa penilaian dilakukan dengan mengumpulkan informasi melalui laporan orang tua berupa dokumentasi proses kegiatan dan hasil karya anak. Selain itu penelitian (Oktarina et al., 2021) juga menjelaskan bahwa penilian dilakukan perminggu berdasarkan video dan foto yang dikirim oleh orang tua. Penelitian senada oleh (Rahma \& Fatonah, 2021) bahwa penilaian perkembangan anak dilakukan dengan mengumpulkan video dan foto yang dkirim kepada guru.

\section{Optimalisasi Peran Orang Tua dalam Pembelajaran Sistem Online Anak Usia Dini pada Masa Pandemi Covid-19}

Peran orang tua sangat penting dan berpengaruh terhadap kegiatan pembelajaran anak terutama pada masa pandemi ini. Peran orang tua makin meluas yang tidak hanya focus pada penanaman nilai agama dan moral, tetapi juga berperan sebagai pendamping akademik anak. Meskipun hal tersebut sudah dilakukan tetapi sepenuhnya dilakukan oleh guru sebelum adanya wabah. Peran guru sebagai pendamping akademik menjadi hal utama saat ini, di mana orang tua harus meluangkan waktu yang banyak untuk mendampingi anak belajar di rumah. Keterlibatan orang tua dalam pembelajaran berdasarkan hasil penelitian ini dapat dilihat pada gambar 3.
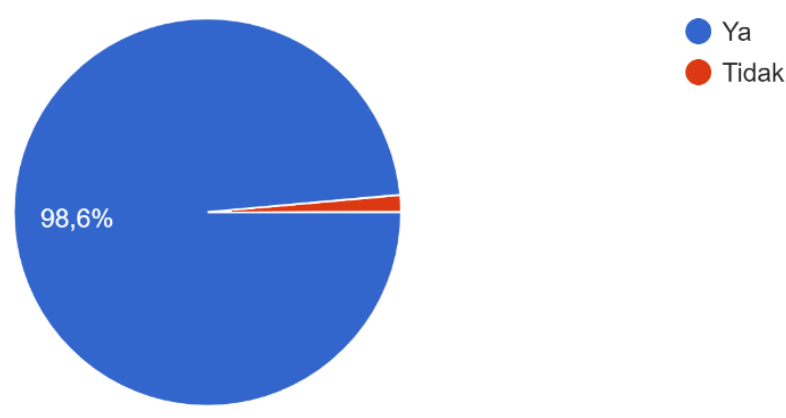

Gambar 4. Keterlibatan Orang Tua dalam Pembelajaran Sistem Online 
Gambar 4 membuktikan bahwa keterlibatan atau peran orang tua dalam pembelajaran sistem online adalah merupakan suatu keharusan. Keterlibatan adalah Kerjasama guru dan orang tua dalam pembelajaran di rumah (Kartini, 2020). Oleh karena itu optimalisasi peran orang tua sangat penting dalam smencapai tujuan pembelajaran. keterlibatan orang tua sebagai perantara guru dan anak didik dalam pembelajaran online merupakan orang tua sebagai fasilitator (Anggraeni et al., 2021). Orang tua merupakan jembatan bagi guru dan anak mencapai tujuan pembelajaran yang ditetapkan. Selain itu guru juga menyediakan fasilitasfasilitas yang menunjang kegiatan pembelajaran di rumah. Berdasarkan hasil wawancara dan kuesioner maka dapat digambarkan tentang peran orang tua dalam pembelajaran sistem online pada masa pandemic covid-19 pada tabel 3.

Tabel 3. Optimalisasi Peran Orang Tua dalam Pembelajaran Sistem Online

\begin{tabular}{|c|c|}
\hline No. & Uraian Kegiatan Orang Tua \\
\hline 1. & $\begin{array}{l}\text { Berkomunikasi dengan guru terkait dokumen RPPM, RPPH dan Lembar } \\
\text { Kegiatan Anak (LKA) }\end{array}$ \\
\hline 2. & $\begin{array}{l}\text { Mendampingi anak saat pembelajaran berlangsung dari awal hingga akhir } \\
\text { pembelajaran }\end{array}$ \\
\hline 3. & Mengawasi dan membimbing anak mengerjakan LKA \\
\hline 4. & Bersama anak membuat video sebagai tugas yang diberikan guru \\
\hline 5. & $\begin{array}{l}\text { Membuat laporan kepada guru dalam bentuk video saat pembelajaran } \\
\text { berlangsung dan mengambil gambar atau foto yang dikirim kepada guru }\end{array}$ \\
\hline 6. & $\begin{array}{l}\text { Menasehati dan memberikan motivasi kepada anak untuk menyelesaikan tugas } \\
\text { yang diberikan guru }\end{array}$ \\
\hline
\end{tabular}

Tabel 3 menggambarkan optimalisasi peran orang tua dalam pembelajaran sistem online dengan pendekatan fungsi manajemen yakni dalam tahap perencanaan, orang tua berkomunikasi dengan guru terkait dokumen RPPM, RPPH dan LKA dengan tujuan agar orang tua memahami materi dan dapat menjelaskan kepada anak. Selanjutnya pada tahap pelaksanaan, orang tua mendampingi anak saat pembelajaran berlangsung, mengawasi dan membimbing anak mengerjakan LKA, sementara itu pada tahap evaluasi, orang tua membuat laporan kepada guru dalam dalam bentuk video, foto dan LKA yang telah dikerjakan. Meskipun orang tua memiliki tanggung jawab yaitu mengurus keperluan keluarga yang lain namun bukan berarti bahwa orang tua tidak mendampingi akademik anak di rumah selama pandemi. Dengan pendampingan akademik yang dilakukan, orang tua dapat melihat secara langsung perkembangan. Ini sejalan dengan penelitian yang dilakukan oleh Nika Cahyati dengan hasil penelitian digambarkan bahwa peran orang tua dalam menerapkan pembelajaran di rumah saat pandemi covid-19 dapat meningkatkan kelekatan hubungan dengan anak dan secara langsung dapat melihat perkembangan kemampuan anak dalam belajar (Cahyati \& Kusuma, 2020). Selain pendampingan yang dilakukan, orang tua juga mengawasi anak dalam menyelesaikan tugas yang diberikan guru serta mengawasi saat pembelajaran berlangsung. Senada dengan hasil penelitian Wardhani \& Krisnani (2020) bahwa optimalisasi pengawasan orang tua dalam pembelajaran online sangat penting bagi terwujudnya hasil belajar yang optimal. Selain itu pengawasan orang tua diberikan dalam bentuk perhatian kepada anak baik saat sebelum pembelajaran dimulai, saat pembelajaran berlangsung dan pembelajaran selesai. Membuat video Bersama sebagai tugas guru dapat menumbuhkan kedekatan orang tua dan anak. Hal ini senada dengan hasil penelitian Safriyani et al. (2021) bahwa kegiatan anak dalam bentuk video dikirimkan kepada guru sebagai bentuk laporan.

Selain melakukan pendampingan, orang tua juga selalu memberikan motivasi dan nasehati anak untuk menyelesaikan tugas yang diberikan guru. hal ini berkaitan dengan hasil penelitian yang dilakukan oleh Yulianingsih bahwa salah salah satu peran orang tua adalah memberikan motivasi (Yulianingsih et al., 2020). Senada dengan hasil penelitian Lilawati 
(2020) bahwa peran orang tua dalam pembelajaran di rumah pada masa pandemi yakni sebagai pendamping dan motivator serta sebagai sumber literasi anak (Hermawati \& Sugito, 2021). Disamping itu orang tua menjadi faktor penentu tercapainya tujuan pendidikan pada anak usia dini dimasa pandemi covid-19 (Tsalisah \& Syamsudin, 2022).

\section{SIMPULAN}

Optimalisasi peran guru dalam sistem pembelajaran online AUD pada masa pandemi covid-19, dilaksanakan dengan memberikan dokumen RPPM dan RPPH kepada orang tua, membuat video tutorial pembelajaran, video call, pembelajaran melalui zoom, WhatsApp dengan dampingan orang tua, membuat alat peraga yang menarik, melakukan penilaian terhadap capaian perkembangan AUD, melakukan Visit Home, mengumpulkan video, foto, LKA dan hasil karya anak. Sedangkan peran orang tua sebagai pendamping akademik dilaksanakan dengan berkomunikasi dengan guru terkait dokumen RPPM, RPPH dan LKA, mendampingi AUD saat pembelajaran, mengawasi, membimbing anak mengerjakan LKA, bersama anak membuat video serta membuat laporan kepada guru.

\section{UCAPAN TERIMA KASIH}

Terima kasih penulis ucapkan kepada guru, orang tua, dan kepala sekolah yang telah bersedia menjadi informan dalam penelitian ini.

\section{DAFTAR PUSTAKA}

Affifah, N. R. (2021). Peranan Pendidik Dalam Pembelajaran Daring Pada Anak Usia Dini Di Masa Pandemi Covid-19 Di Kecamatan Sleman. JPP PAUD FKIP Untirta, 8(November), 93-100.

Alfiah, L. N., Rokhim, D. A., \& Wulandari, I. A. I. (2020). Analisis Dampak Anjuran Pemerintah Terhadap Belajar Di Rumah Bagi Pelaku Pendidikan. Jurnal Administrasi Dan Manajemen Pendidikan, 3(3), 216-223. https://doi.org/10.17977/um027v3i32020p216

Anggraeni, N., Fakhriyah, F., Ahsin, M. N., Dasar, G. S., Kudus, U. M., \& Kudus, U. M. (2021). Peran orang tua sebagai fasilitator anak dalam proses pembelajaran online di rumah 1. VIII(2), 105-117. https://doi.org/10.30659/pendas.8.2.105-117

Arifa, F. N. (2020). Tantangan Pelaksanaan Kebijakan Belajar Dari Rumah Dalam Masa Darurat Covid-19. Info Singkat;Kajian Singkat Terhadap Isu Aktual Dan Strategis, XII(7/I), 6. http://berkas.dpr.go.id/puslit/files/info_singkat/Info Singkat-XII-7-IP3DI-April-2020-1953.pdf

Asmidarwati, Salmiati, Z. R. (2020). Analisis Perkembangan Motorik Kasar Anak Dalam Pembelajaran Daring Pada Anak Tk Save The Kids Banda Aceh. Ilmiah Mahasiswa, 2(1).

Astuti, I. Y., \& Harun, H. (2020). Tantangan Guru dan Orang Tua dalam Kegiatan Belajar Dari Rumah Anak Usia Dini pada Masa Pandemi Covid-19. Jurnal Obsesi: Jurnal Pendidikan Anak Usia Dini, 5(2), 1454-1463. https://doi.org/10.31004/obsesi.v5i2.808

Cahyati, N., \& Kusuma, R. (2020). Peran Orang Tua Dalam Menerapkan Pembelajaran Di Rumah Saat Pandemi Covid 19. Jurnal Golden Age, 4(01), 152-159. https://doi.org/10.29408/jga.v4i01.2203

Darmadi, H. (2015). Tugas, Peran, Kompetensi dan Tanggung Jawab Menjadi Guru Profesional. Edukasi, 13(2), 161-174.

Dewi, M. (2020). Analisis Kerja Sama Guru Dengan Orang Tua Dalam Pembelajaran Online Di Era Covid 19 Di Mi Azizan Palembang. JEMARI (Jurnal Edukasi Madrasah Ibtidaiyah), 2(2), 54-64. https:// doi.org/10.30599/jemari.v2i2.661

Fadlillah, M. (2019). Bermain dan Permainan Anak Usia Dini (3rd ed.). Prenadamedia Grup. 
Hasanah, U. (2018). Metode Pengembangan Moral Dan Disiplin Bagi Anak Usia Dini. Martabat: Jurnal Perempuan Dan Anak, 2(1). https://doi.org/10.21274/martabat.2018.2.1.91-116

Hermawati, N. S., \& Sugito, S. (2021). Peran Orang Tua dalam Menyediakan Home Literacy Environment (HLE) pada Anak Usia Dini. Jurnal Obsesi : Jurnal Pendidikan Anak Usia Dini, 6(3), 1367-1381. https://doi.org/10.31004/obsesi.v6i3.1706

Iftitah, S. L., \& Anawaty, M. F. (2020). Peran Orang Tua Dalam Mendampingi Anak Di Rumah Selama Pandemi Covid-19. JCE (Journal of Childhood Education), 4(2), 71. https://doi.org/10.30736/jce.v4i2.256

Indah, Kinzler, K. W., Vogelstein, B., Vogelstein, J. T., Athey, S., Zhou, S., Bettegowda, C., Nanjwade, B. K., Close, M., Kecerdasan, I., Ikep, P., Book, R., Marks, R., Unal, M., Irez, T., Antao, V. C., Muravov, O. I., Sapp, J., Larson, T. C., ... Indah Winarsih, I. P. R. (2020). Peranan Guru Dalam Pembelajaran Daring Pada Masa Pandemi Covid-19. Endocrine, 9(May), 6.

Kartini, Y. (2020). Kerjasama Orang Tua Dan Guru Dalam Penyelenggaraan Pembelajaran Online Sebagai Upaya Pencegahan Virus Corona Di Mi Muhammadiyah Pasirmuncang. Qalam: Jurnal Pendidikan Islam, 1(20), 77-91.

Kemala, A., \& Rohman, A. (2021). Penilaian Perkembangan Anak Selama Belajar dari Rumah di Era Pandemic Covid-19. Jurnal Obsesi : Jurnal Pendidikan Anak Usia Dini, 6(2), 1044-1053. https://doi.org/10.31004/obsesi.v6i2.1129

Kurniati, E., Nur Alfaeni, D. K., \& Andriani, F. (2020). Analisis Peran Orang Tua dalam Mendampingi Anak di Masa Pandemi Covid-19. Jurnal Obsesi : Jurnal Pendidikan Anak Usia Dini, 5(1), 241. https:// doi.org/10.31004/obsesi.v5i1.541

Lilawati, A. (2020). Peran Orang Tua dalam Mendukung Kegiatan Pembelajaran di Rumah pada Masa Pandemi. Jurnal Obsesi: Jurnal Pendidikan Anak Usia Dini, 5(1), 549. https://doi.org/10.31004/obsesi.v5i1.630

Nirmala, B., \& Annuar, H. (2020). Home Visit: Strategi PAUD dari Rumah bagi Guru di Daerah 3T pada Masa Pandemi Covid-19. Jurnal Obsesi : Jurnal Pendidikan Anak Usia Dini, 5(2), 1052-1062. https://doi.org/10.31004/obsesi.v5i2.716

Oktarina, A., Fatonah, S., Islam, U., Sunan, N., \& Yogyakarta, K. (2021). Pengamatan Tentang Pembelajaran Dan Penilaian. 12(1), 31-40. https:// doi.org/10.17509/cd.v12i1.30278

Pertiwi, L. K., Febiyanti, A., \& Rachmawati, Y. (2021). Keterlibatan Orang Tua Terhadap Pembelajaran Daring Anak Usia Dini Pada Masa Pandemi Covid-19. Cakrawala Dini: Jurnal Pendidikan Anak Usia Dini, 12(1), 19-30. https://doi.org/10.17509/cd.v12i1.26702

Rahma, Z., \& Fatonah, S. (2021). Penilaian Perkembangan Anak Usia Dini Di Era Covid-19. Yaa Bunayya : Jurnal Pendidikan Anak Usia Dini, 5(1), 34-43.

Rahmatullah, Inanna, Nurlinda, Rahmadani, S. S., \& Wahyuni, M. (2021). Efektifitas Peran Guru dan Orang Tua Dalam Pembelajaran Daring Selama Pandemi Covid-19. Proceeding Teknologi Pendidikan Seminar Daring Nasional 2021: Digital Generation For Digital Nation, 34-39.

Rendy, S. T. F. (2020). Keterampilan Guru PAUD Kabupaten Ponorogo Dalam Memberikan Penguatan Selama Masa Pandemi COVID-19. Jurnal Golden Age, 4(01), 100-111. https://doi.org/10.29408/iga.v4i01.2167

Riski Maulinda Sari, Rodhatul Jennah, S. U. R. (2021). The Implementation of Learning Assesment during the Covid- 19 Pandemic on TK Islam Darussalam Palangkaraya. Awlady, 7(2), 238-250. https://doi.org/10.24235/awlady.v7i2.8393

Safriyani, R., Wakhidah, E. W., \& Supriyanto, C. (2021). Online Learning Strategies During Covid-19 in an Early Childhood Education. Musamus Journal of Primary Education, 3(2), 145-156. https://doi.org/10.35724/musjpe.v3i2.3227

Sitti Maemunawati, M. A. (2020). Peran Guru, Orang Tua, Metode dan Media Pembelajaran: Strategi KBM Di Masa Pandemi (1st ed.). Penerbit 3M Media Karya. 
Sundari, F. (2017). Peran Guru Sebagai Pembelajar dalam Memotivasi Peserta Didik Usia SD. Syafi'i, I., Sa'diyah, C., Wakhidah, E. W., \& Umah, F. M. (2020). Penerapan Video Pembelajaran Daring Anak Usia Dini Pada Masa Pandemi Covid-19 Pertama Kali Di Indonesia. AlAthfaal: Jurnal Ilmiah Pendidikan Anak Usia Dini, 3(2), 140-160. https:// doi.org/10.24042/ajipaud.v3i2.7315

Tsalisah, N. H., \& Syamsudin, A. (2022). Dampak Pembelajaran Daring terhadap Proses Belajar Anak Usia Dini. Jurnal Obsesi : Jurnal Pendidikan Anak Usia Dini, 6(3), 23912403. https://doi.org/10.31004/obsesi.v6i3.1958

Wahyuni, R. A. (2021). Penerapan Video Pembelajaran Daring Anak Usia Dini Pada Masa pandemi Covid-19. Syntax Transformation, 2(7), 1037-1048. https://doi.org/10.33474/thufuli.v2i1.6925

Wardhani, T. Z. Y., \& Krisnani, H. (2020). Optimalisasi Peran Pengawasan Orang Tua Dalam Pelaksanaan Sekolah Online Di Masa Pandemi Covid-19. Prosiding Penelitian Dan Pengabdian Kepada Masyarakat, 7(1), 48. https://doi.org/10.24198/jppm.v7i1.28256

Yulianingsih, W., Suhanadji, S., Nugroho, R., \& Mustakim, M. (2020). Keterlibatan Orangtua dalam Pendampingan Belajar Anak selama Masa Pandemi Covid-19. Jurnal Obsesi: Jurnal Pendidikan Anak Usia Dini, 5(2), 1138-1150. https://doi.org/10.31004/obsesi.v5i2.740 